\title{
EXAMINING THE LONG TERM MORTALITY EFFECTS OF EARLY HEALTH SHOCKS
}

\author{
by
}

\author{
Jason M. Fletcher* \\ University of Wisconsin-Madison
}

\begin{abstract}
CES 14-19
March, 2014

The research program of the Center for Economic Studies (CES) produces a wide range of economic analyses to improve the statistical programs of the U.S. Census Bureau. Many of these analyses take the form of CES research papers. The papers have not undergone the review accorded Census Bureau publications and no endorsement should be inferred. Any opinions and conclusions expressed herein are those of the author(s) and do not necessarily represent the views of the U.S. Census Bureau. All results have been reviewed to ensure that no confidential information is disclosed. Republication in whole or part must be cleared with the authors.

To obtain information about the series, see www.census.gov/ces or contact Fariha Kamal, Editor, Discussion Papers, U.S. Census Bureau, Center for Economic Studies 2K132B, 4600 Silver Hill Road, Washington, DC 20233, CES.Papers.List@census.gov.
\end{abstract}




\begin{abstract}
A growing literature in economics and other disciplines has tied exposure to early health shocks, particularly in utero influenza, to reductions in a variety of socioeconomic and health outcomes over the life course. However, no current evidence exists that examines this health shock on mortality because of lack of available data. This paper uses newly released files from the large, representative National Longitudinal Mortality Study to explore the mortality effects of the 1918 influenza pandemic for those in utero. While the results on socioeconomic outcomes mimic those in the literature, showing reductions in completed schooling and income fifty years following influenza exposure, the findings also suggest no effect on overall mortality or by categories of cause-of-death. These results are counter-intuitive in their contrast with the many reported effects on cardiovascular health as well as the literature linking education with later mortality.
\end{abstract}

* I thank the NYC RDC for access to the data and Jonathan Fisher for his assistance with the data and RDC policies. I thank Norm Johnson for help in granting initial access of the NLMS data within the RDC. I acknowledge research support from the Robert Wood Johnson Foundation Health \& Society Scholars Program. The research in this paper was conducted while the author was a Special Sworn Status researcher of the U.S. Census Bureau at the NYC Census Research Data Center. Research results and conclusions expressed are those of the authors and do not necessarily reflect the views of the Census Bureau. This paper has been screened to insure that no confidential data are revealed 


\section{$\underline{\text { Introduction }}$}

Estimating the existence and magnitude of long term consequences of health insults that occur during early development have been of long standing interest to social science researchers. While there are many earlier precedents for this interest, the so-called "Barker Hypothesis" (Barker 1992) has refocused attention on the potential importance of "fetal programming" - the effects of environmental shocks to health, such as nutritional deprivation in utero, that may affect the development of biological systems that have implications in later life. Although there is widespread evidence supporting this hypothesis from animal models, which allow an explicit experimental research design and relatively clear causal inference, there has been limited convincing research in human populations because of the limited ability to harness similar research designs. However, recent research in this area has focused on leveraging plausibly exogenous shocks to early health conditions combined with rich data sources in an attempt to produce causal evidence.

Many researchers, economists in particular, have attempted to exploit variation stemming from relatively short-lived environmental shocks and disasters such as famines, earthquakes, and influenza outbreaks to examine the long term effects on individuals in utero during the events, in comparison to individuals in utero soon before or soon after the events. Several papers leverage important features of the 1918 flu in order to produce causal estimates. Most importantly, the pandemic struck without warning in October 1918, diffused nationwide in about one month (Sydenstricker 1918), and was over by early 1919, implying that children in utero separated by only a few months were exposed to very different conditions. In a series of papers, the effects of the exposure to the flu has been shown to reduce educational attainment, income, and socioeconomic status and increase physical disability, cardiovascular disease, and diabetes and stroke (Almond 2006, Almond and Mazumder 2005, Mazumder et al. 2010).

In contrast to this work, there is very limited evidence of the potential of long term mortality effects of the 1918 flu. The only published research is inconclusive, where the authors use coarse data from 24 countries and find no mortality effects (Cohen et al. 2009). The goal of this paper is to further examine the potential for mortality effects as well as 
replicate and extend the results from Almond (2006). Almond (2006) used Decennial Census Data. In contrast, this study uses data from the restricted National Longitudinal Mortality Study (NLMS). Data from the restricted NLMS are matched to date of birth information (to measure flu exposure in utero) to mortality data as well as socioeconomic outcomes available in the data that were measured around 1980, when the potentially affected cohorts would be approximately 60 years old.

\section{Background Literature}

The effects of early circumstances on life time outcomes have been the subject of a large set of previous work in a variety of disciplines. Much of the research in each of the disciplines is motivated, at least in part, by the so-called "Fetal Origins Hypothesis" or "Barker Hypothesis" (Barker 1992), which focuses on the early sources of later chronic conditions by examining the course of fetal development. There are several major limitations in tests that examine the fetal origins hypothesis in humans. Experimental designs are ethically problematic, so that observational studies are typically used. This limitation then opens up the issue of whether omitted variables might be responsible for the correlations found in many datasets between early health and later outcomes. A second issue with exploring this research question in human populations is the long period of latency between early conditions and later outcomes, maybe 50 or more years in humans, which requires rich data that are often unavailable.

As outlined above, a key innovation that has merged the epidemiological focus on specific environmental conditions that may impact fetal development (e.g. famines) with the social science focus on identifying causal effects is the series of studies by Almond and coauthors that have leveraged the 1918 flu pandemic to examine long term effects of this large and specific environmental shock for individuals in utero. In particular, Almond (2006) combined birth quarter information from the 1960-1980 US Decennial Census files with socioeconomic and health related measurements during these years, 40-60 years after the exposure to the flu pandemic. For example, figure 1 (taken from Almond 2006) shows visual evidence of a large increase in disability rates at age 60 for individuals in utero in quarters 
coinciding with the flu pandemic. The author goes on to produce similar evidence for reductions in years of schooling and income and increases in transfer payment receipt.

Figure 1 (Almond 2006)

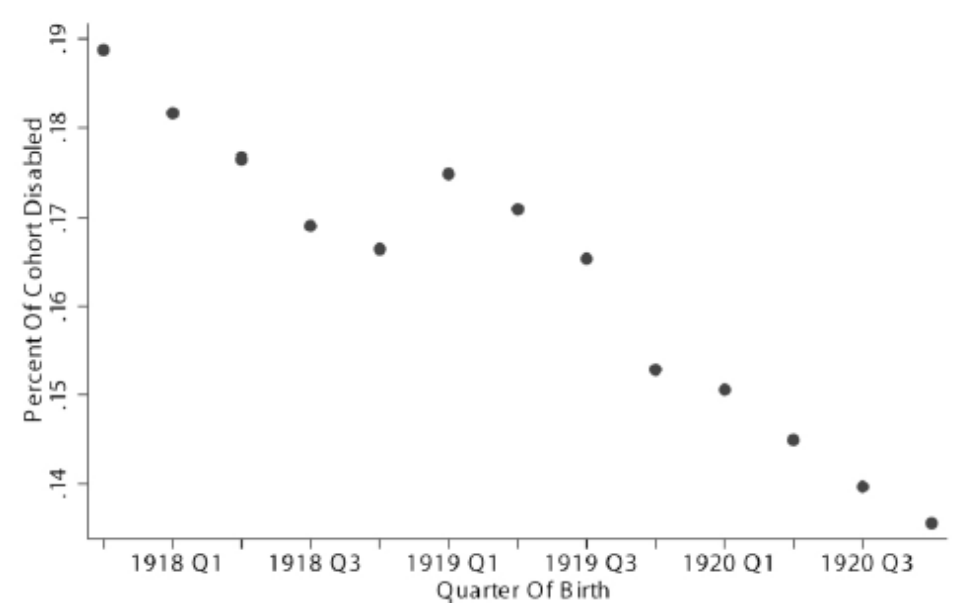

Likewise, Almond and Mazumder (2005) use SIPP data to show associations between birth cohort and stroke and diabetes, and Mazumder et al. (2010) have recently used data from the National Health Interview Survey to show associations between birth cohort and cardiovascular disease.

While this large and growing list of conditions and outcomes has been found to be strongly associated with birth cohort, much less research has focused on mortality outcomes. The only published paper in the literature to examine this relationship is Cohen et al. (2009), which uses coarse cohort-level data from 24 developed countries. While the authors find no residual correlations between affected birth cohorts and mortality, analyses using richer individual data are still lacking. No existing evidence has been able to examine links between the 1918 flu exposure and mortality by cause of death and no other research has used the NLMS to answer this type of question.

\section{Data}

The NLMS was collected to examine the effects of demographic and socioeconomic characteristics on differentials in mortality. To do this, records from the Current Population Surveys (CPS) from years 1979-1996 are matched to mortality information from death 
certificates available for deceased persons through the National Center for Health Statistics (NCHS). Extensive demographic, social, economic, and occupational information is collected in the CPS. The study consists of more than 2.3 million records with over 250,000 identified mortality cases. So, the dataset is cross-sectional with the only "panel" component being mortality outcomes ${ }^{2}$.

This study has two primary sets of dependent variables-mortality outcomes and socioeconomic status outcomes. In order to replicate Almond (2006), this study will examine the relationship between flu exposure in utero and several dependent variables, including highest grade completed, employment status, adjusted income, marital status, and home ownership status.

In the mortality analysis, the primary dependent variables in this study include the death indicator variable, which is measured through 2001, and the 3 and 4 digit cause of death variables. These cause of death variables will be collapsed into relevant subgroups (e.g. cardiovascular or accident). Table 1 provides summary statistics for the sample born between 1915-1923. The probability of mortality through 2001 is $35 \%$. Note that the analyses will control for survey year fixed effects in order to hold constant survival until the survey collection. The average years of schooling completed is 11.05 (similar to Almond 2006, which ranges from 10.6 to 11.2 depending on the sample). The high school graduate rate is $57 \%$ (Almond is $50-54 \%$ ), the proportion disabled is 3\% (Almond is 6-8\%). The proportion "treated" (i.e. born in 1919) is $11 \%$ of the sample.

\section{Methods}

Following the previous literature on this topic, several sets of regression analysis will be used to examine the effects of exposure to the $1918 \mathrm{flu}$ in utero on later outcomes. The key "treatment" variable is whether the individual was in utero during the flu pandemic, which,

\footnotetext{
${ }^{2}$ While the public use data contains nearly all the necessary information to examine this research question, it does not contain two key elements-month and year of birth and state of residence at birth. Although the public use data contains age, the year the individual was in the CPS has been removed from the public use NLMS data and several CPS data waves have been collapsed into a single file with no identifier for the survey year from the CPS. Thus, the year of birth is unknown in the public file.
} 
while short lived, stretched from October 1918-April 1919 so that individuals born during the final quarter of 1918 and throughout 1919 were potentially exposed. These "treated" individuals will be compared to individuals born in adjacent years. Following much of the current research, the regression will be estimated for cohorts born between 1915-1923 (Mazumder et al. 2010). The main regression specification will be:

$$
y_{i}^{t}=\beta_{0}+\beta_{1} I(Y O B=1919)+\beta_{2} Y O B+\beta_{3} Y O B^{2}+\varepsilon_{i}
$$

where $y_{i}^{t}$ denotes an outcome measured at time $t$ for individual $i$. These outcomes include mortality, years of education, and those listed in the data section. $I(\bullet)$ denotes the indicator function, YOB measures the birth year and $\beta_{1}$ is the coefficient of interest, measuring the departure of outcomes for the 1919 birth cohort from the quadratic cohort trend. The expectation is $\beta_{1}$ will be negative for the socioeconomic status outcomes, which would match the results in Almond (2006), who uses Decennial Census data. And $\beta_{1}$ is hypothesized to be positive in the specifications that examine mortality-suggesting those who were in utero during the 1918 flu epidemic (and survived) are more likely to die early. The estimates will be pooled but also separated by gender and race.

\section{$\underline{\text { Results }}$}

Table 2 presents results in the spirit of Almond 2006. Controlling for survey year and state of birth fixed effects, the results suggest a 0.068 reduction in years of schooling for the pooled sample. Almond finds a 0.11 reduction for males and a 0.071 reduction for females using the 1980 Census waves. My smaller estimate is consistent with the trend in Almond that the coefficient is reduced in each subsequent Census data wave (from 1960-1980). Column 2 shows a 1.5 percentage point reduction in high school graduation (Almond finds 1.4 and 1.5 for men and women, respectively, in 1980). Column 3 finds no effect for the likelihood of college graduation.

Columns 4-6 examine labor market outcomes. Column 4 finds no effects on whether an individual is currently employed (and the standard errors can rule out even small effects). However, Column 5 shows a 2\% reduction in current income and Column 6 shows that 
individuals born in 1919 are in occupations with lower status (as measured by average education).

Table $2 \mathrm{~b}$ extend the analysis to marital, disability, and housing outcomes. Columns 1 and 2 show that individuals born in 1919 do not differ in the likelihood of being married at the time of the survey but are less likely to be never married. Column 3 shows no association between exposure to in utero influenza and current reported disability status, unlike Almond (2006) who finds moderate effects ( $0.5 \%$ off a base of $25 \%)$. Column 4 finds no relationship with whether the individual is living in a rural (vs. urban) area at the time of the survey. Column 5 finds small but statistically significant reductions in the likelihood of owning a home.

Since I am able to replicate many of the qualitative findings of Almond (2006) that individuals born in 1919 have worse education and labor market outcomes 20-60 years later, I next examine whether these impacts affect later mortality. In general, the results in Table 3 suggest no effects of in utero influenza exposure on increased mortality risk, conditional on survey year. The precision of the estimates can also rule out relatively large (2 pp) effects. Separating the sample by gender and race shows that the results are robust. Figure 1 presents a non-parametric figure of death rates by birth cohort and again shows no evidence of changes for the 1919 birth cohort, but instead shows a smooth downward trend.

Because the earlier results have suggested that exposure to influenza in utero also reduces years of schooling by approximately 0.07 years and some of the literature on compulsory schooling laws suggest these laws affect years of schooling by a similar magnitude, these results also indirectly question some of the evidence linking education with mortality more generally. Most famously, Lleras-Muney (2005) used compulsory schooling laws as instruments for education to show that an increase of one year of schooling reduced mortality by approximately 8 percentage points. However, the results in this paper are more consistent with evidence from Clark and Royer (in press) that found no mortality effect from educational increases.

To further example the plausibility of lasting mortality effects from the 1918 flu pandemic for those in utero, Table 4 explores whether specific causes of mortality appear to be affected using the 3-digit cause of death codes aggregated into 17 groups. 2 categories are not 
listed because they involve infant death. Again, the estimates suggest limited evidence of lasting mortality effects. The only category with a statistically significant estimate is for mental disorders, but the sign is in the unexpected direction (suggesting reduced mortality from influenza exposure). Otherwise, all coefficients are quiet small and not statistically significant.

\section{Conclusions}

This paper has presented the first evidence in the literature of whether there is a link between long term mortality and exposure in utero to the 1918 influenza epidemic. A host of papers have shown important effects on adult human capital and health outcomes, but no data in the US has been available to examine mortality outcomes. I use a restricted version of the Current Population Survey linked with the National Death Index (i.e. the National Mortality Longitudinal Study) that includes birth date and state of birth information. Although I replicate previous findings of lower human capital attainment and worse labor market outcomes or those exposed, I find no evidence of mortality effects of in utero influenza exposure. These results question the mechanism linking in utero exposure to adult outcomes already in the literature and also question purported links between human capital and later mortality outcomes. Making sense of these findings will require additional research. 


\section{$\underline{\text { References }}$}

Almond, Douglas. (2006). "Is the 1918 Influenza Pandemic Over? Long-Term Effects of In Utero Influenza Exposure in the Post 1940 Population." Journal of Political Economy, 114 (4): 672-712

Almond, Douglas, and Bhashkar Mazumder. 2005. "The 1918 Influenza Pandemic and Subsequent Health Outcomes: An Analysis of SIPP Data." American Economic Review Papers and Proceedings, 95: 258-62.

Barker, David J. P., ed. 1992. Fetal and Infant Origins of Adult Disease: Papers. London: British Medical J

Black, Sandra E., Paul J. Devereux, and Kjell G. Salvanes. 2005. "From the Cradle to the Labor Market? The Effect of BirthWeight on Adult Outcomes."Working Paper no. 11796 (November), NBER, Cambridge, MA.

Clark, Damon and Heather Royer. (in press). The Effect of Education on Mortality and Health: Evidence from Britain. AER

Cohen, Alan. A, John Tillinghast, and Vladimir Canuda-Romo. (2009). "No Consistent Effects of Prenatal or Neonatal Exposure to Spanish Flu on Late-Life Mortality in 24 Developed Countries." Demographic Research, 22 (20): 579-634

Fletcher, Jason. (2011). "The Medium Term Effects of Low Birth Weight." Economics of Education Review.

Kannisto, V., Christensen, K., and Vaupel, J.W. (1997). No increased mortality in later life for cohorts bom during famine. American Journal of Epidemiology 145(11): 987-994.

Mazumder, B, D. Almond, K. Park, EM. Crimmins, and CE Finch. (2010). "Lingering Prenatal Effects of the 1918 Influenza Pandemic on Cardiovascular Disease." Journal of Developmental Origins of Health and Disease, 1(1): 26-34

Oreopoulos, Phil, Mark Stabile, Randy Walld, and Leslie Roos. 2006. "Short, Medium, and LongTerm Consequences of Poor Infant Health: An Analysis Using Siblings and Twins." Working Paper no. 11998 (February), NBER, Cambridge,MA.

Roseboom, T. J., et al. 2000. "Coronary Heart Disease after Prenatal Exposure to the Dutch Famine, 1944-45." Heart 84 (December 1): 595-98.

Roseboom, T. J., J. H. van der Meulen, A. C. Ravelli, C. Osmond, D. J. Barker, and O. P. Bleker. 2001. "Effects of Prenatal Exposure to the Dutch Famine on Adult Disease in Later Life: An Overview." Twins Res. 4 (October): 293-98. 
Royer, Heather. 2009. "Separated at Girth: Estimating the Long-Run and Intergenerational Effects of Birthweight Using Twins." American Economic Journal: Applied Economics

Stanner, S.A., Bulmer,K., Andrès, C., Lantseva, O.E., Borodina, V., Poteen, V.V., and Yudkin, J.S. (1997). Does malnutrition in utero determine diabetes and coronary heart disease in adulthood? Results from the Leningrad siege study, a cross sectional study. British Medical Journal 315: 1342-1348.

Sydenstricker, E. 1918. "Preliminary Statistics of the Influenza Epidemic." Public Health Reports 33 (December): 2305-21. 
Tables

Table 1

Descriptive Statistics

National Longitudinal Mortality Study

Birth Cohorts 1915-1923

\begin{tabular}{|lccc|}
\hline Variable & $\mathrm{N}$ & Mean & $\mathrm{SD}$ \\
Mortality & 147942 & 0.35 & 0.48 \\
Education & 147942 & 11.05 & 3.29 \\
HS Grad & 147942 & 0.57 & 0.49 \\
College Grad & 147942 & 0.10 & 0.31 \\
Log (Income) & 147942 & 9.57 & 0.94 \\
Married & 147942 & 0.71 & 0.45 \\
Never Married & 147942 & 0.05 & 0.21 \\
Widowed & 147942 & 0.16 & 0.37 \\
Divorced & 147942 & 0.05 & 0.22 \\
Separated & 147942 & 0.02 & 0.13 \\
Retired & 147942 & 0.57 & 0.50 \\
Disabled & 147942 & 0.03 & 0.17 \\
Employed & 147942 & 0.36 & 0.48 \\
Rural & 147942 & 0.31 & 0.46 \\
Own Home & 147942 & 0.82 & 0.39 \\
Year of Birth $=1919$ & 147942 & 0.11 & 0.31 \\
First Trimester & 147942 & 0.11 & 0.31 \\
Second Trimester & 147942 & 0.08 & 0.27 \\
Third Trimester & 147942 & 0.08 & 0.27 \\
Month of Birth & 147942 & 6.49 & 3.44 \\
Female & 147942 & 0.54 & 0.50 \\
Black & 147942 & 0.08 & 0.27 \\
Hispanic & 147942 & 0.03 & 0.18 \\
Asian & 147942 & 0.01 & 0.11 \\
Other Race & 147942 & 0.00 & 0.06 \\
\hline
\end{tabular}

Notes: Census Bureau does not allow reporting of minimum and maximum values 
Table 2

Adult Outcomes Associated with a 1919 Birth Year

Education and Labor Market Outcomes

\begin{tabular}{|c|c|c|c|c|c|c|}
\hline $\begin{array}{l}\text { Outcome } \\
\text { Fixed Effects? }\end{array}$ & $\begin{array}{c}\text { Education } \\
\text { Survey Wave, POB }\end{array}$ & $\begin{array}{c}\text { HS Grad } \\
\text { Survey Wave, POB }\end{array}$ & $\begin{array}{c}\text { College Grad } \\
\text { Survey Wave, POB }\end{array}$ & $\begin{array}{l}\text { Current Employed } \\
\text { Survey Wave, POB }\end{array}$ & $\begin{array}{c}\text { Log (Income) } \\
\text { Survey Wave, POB }\end{array}$ & $\begin{array}{c}\text { Occupational Education } \\
\text { Survey Wave, POB }\end{array}$ \\
\hline Year of Birth = 1919 & $\begin{array}{c}-0.068 * \\
(0.04)\end{array}$ & $\begin{array}{c}-0.015^{* * *} \\
(0.00)\end{array}$ & $\begin{array}{l}-0.001 \\
(0.00)\end{array}$ & $\begin{array}{l}-0.003 \\
(0.01)\end{array}$ & $\begin{array}{c}-0.024^{* * *} \\
(0.01)\end{array}$ & $\begin{array}{c}-0.036^{* * *} \\
(0.01)\end{array}$ \\
\hline Year of Birth & $\begin{array}{l}0.224 * * * \\
(0.08)\end{array}$ & $\begin{array}{c}0.045^{* * *} \\
(0.02)\end{array}$ & $\begin{array}{l}-0.003 \\
(0.01)\end{array}$ & $\begin{array}{c}0.077^{* *} \\
(0.03)\end{array}$ & $\begin{array}{c}0.116^{* * *} \\
(0.03)\end{array}$ & $\begin{array}{c}0.131^{* *} \\
(0.06)\end{array}$ \\
\hline Year of Birth - Squared & $\begin{array}{l}-0.003^{*} \\
(0.00)\end{array}$ & $\begin{array}{c}-0.001^{* *} \\
0.00\end{array}$ & $\begin{array}{c}0 \\
0.00\end{array}$ & $\begin{array}{l}-0.001 \\
(0.00)\end{array}$ & $\begin{array}{l}-0.002^{* * *} \\
(0.00)\end{array}$ & $\begin{array}{l}-0.002 \\
(0.00)\end{array}$ \\
\hline Female & $\begin{array}{c}-0.095^{* * *} \\
(0.03)\end{array}$ & $\begin{array}{c}0.018^{* * *} \\
(0.01)\end{array}$ & $\begin{array}{l}-0.053^{* * *} \\
(0.00)\end{array}$ & $\begin{array}{c}-0.197 * * * \\
(0.02)\end{array}$ & $\begin{array}{l}-0.264^{* * *} \\
(0.00)\end{array}$ & $\begin{array}{c}-0.429 * * * \\
(0.03)\end{array}$ \\
\hline Black & $\begin{array}{c}-2.286 * * * \\
(0.17)\end{array}$ & $\begin{array}{c}-0.295^{* * *} \\
(0.02)\end{array}$ & $\begin{array}{c}-0.062 * * * \\
(0.00)\end{array}$ & $\begin{array}{c}-0.030 * * * \\
(0.01)\end{array}$ & $\begin{array}{c}-0.542^{* * *} \\
(0.01)\end{array}$ & $\begin{array}{c}-0.431^{* * *} \\
(0.02)\end{array}$ \\
\hline Hispanic & $\begin{array}{c}-3.665^{* * *} \\
(0.11)\end{array}$ & $\begin{array}{c}-0.350^{* * *} \\
(0.01)\end{array}$ & $\begin{array}{c}-0.072 * * * \\
(0.01)\end{array}$ & $\begin{array}{c}-0.044^{* * *} \\
(0.01)\end{array}$ & $\begin{array}{c}-0.363^{* * *} \\
(0.01)\end{array}$ & $\begin{array}{c}-0.356^{* * *} \\
(0.03)\end{array}$ \\
\hline Asian & $\begin{array}{c}-1.855^{* * *} \\
(0.21)\end{array}$ & $\begin{array}{c}-0.185^{* * *} \\
(0.03)\end{array}$ & $\begin{array}{l}-0.025 \\
(0.02)\end{array}$ & $\begin{array}{l}-0.003 \\
(0.01)\end{array}$ & $\begin{array}{c}-0.150^{* *} \\
(0.07)\end{array}$ & $\begin{array}{c}-0.239 * * * \\
(0.03)\end{array}$ \\
\hline Other Race & $\begin{array}{c}-1.339 * * * \\
(0.01)\end{array}$ & $\begin{array}{l}-0.112^{* * *} \\
\quad(0.00)\end{array}$ & $\begin{array}{l}0.010^{* * *} \\
0.00\end{array}$ & $\begin{array}{c}0.030 * * * \\
(0.00)\end{array}$ & $\begin{array}{l}0.264 * * * \\
(0.00)\end{array}$ & $\begin{array}{c}-0.019 * * * \\
(0.00)\end{array}$ \\
\hline Constant & $\begin{array}{c}8.318^{* * *} \\
(0.76)\end{array}$ & $\begin{array}{l}0.038 \\
(0.15)\end{array}$ & $\begin{array}{c}0.137 * * * \\
(0.04)\end{array}$ & $\begin{array}{l}-0.283 \\
(0.34)\end{array}$ & $\begin{array}{c}8.531 * * * \\
(0.33)\end{array}$ & $\begin{array}{l}10.213^{* * *} \\
(0.57)\end{array}$ \\
\hline Observations & 147942 & 147942 & 147942 & 147942 & 147942 & 147942 \\
\hline R-squared & 0.11 & 0.105 & 0.019 & 0.208 & 0.103 & 0.122 \\
\hline
\end{tabular}

Notes: Robust standard errors in parentheses, clustered at the state of birth level. ${ }^{* * *} p<0.01,{ }^{* *} p<0.05,{ }^{*} p<0.1$. POB: Place

(state) of birth. Occupational education is the average educational level of individuals in the chosen occupation (within sample). 
Table $2 b$

Adult Outcomes Associated with a 1919 Birth Year

Other Outcomes

\begin{tabular}{|c|c|c|c|c|c|}
\hline $\begin{array}{l}\text { Outcome } \\
\text { Fixed Effects? }\end{array}$ & $\begin{array}{c}\text { Current Married } \\
\text { Survey Wave, POB }\end{array}$ & $\begin{array}{c}\text { Never Married } \\
\text { Survey Wave, POB }\end{array}$ & $\begin{array}{c}\text { Disabled } \\
\text { Survey Wave, POB }\end{array}$ & $\begin{array}{c}\text { Rural } \\
\text { Survey Wave, POB }\end{array}$ & $\begin{array}{c}\text { Own Home } \\
\text { Survey Wave, POB }\end{array}$ \\
\hline Year of Birth $=1919$ & $\begin{array}{l}0.002 \\
(0.00)\end{array}$ & $\begin{array}{c}-0.004^{* * *} \\
(0.00)\end{array}$ & $\begin{array}{l}0.002 \\
(0.00)\end{array}$ & $\begin{array}{l}0.001 \\
(0.00)\end{array}$ & $\begin{array}{c}-0.009 * * * \\
(0.00)\end{array}$ \\
\hline Year of Birth & $\begin{array}{c}0.031^{* * *} \\
(0.01)\end{array}$ & $\begin{array}{l}0.002 \\
(0.00)\end{array}$ & $\begin{array}{c}-0.006^{* *} \\
(0.00)\end{array}$ & $\begin{array}{l}-0.003 \\
(0.01)\end{array}$ & $\begin{array}{c}0.030 * * * \\
(0.01)\end{array}$ \\
\hline Year of Birth - Squared & $\begin{array}{c}-0.001^{*} \\
0.00\end{array}$ & $\begin{array}{c}0 \\
0.00\end{array}$ & $\begin{array}{c}0.000^{*} \\
0.00\end{array}$ & $\begin{array}{c}0 \\
0.00\end{array}$ & $\begin{array}{c}-0.001^{* * *} \\
0.00\end{array}$ \\
\hline Female & $\begin{array}{c}-0.213^{* * *} \\
(0.02)\end{array}$ & $\begin{array}{c}-0.003^{* *} \\
(0.00)\end{array}$ & $\begin{array}{c}-0.020 * * * \\
(0.00)\end{array}$ & $\begin{array}{c}-0.024 * * * \\
(0.00)\end{array}$ & $\begin{array}{c}-0.040 * * * \\
(0.01)\end{array}$ \\
\hline Black & $\begin{array}{c}-0.214^{* * *} \\
(0.01)\end{array}$ & $\begin{array}{c}0.019 * * * \\
(0.01)\end{array}$ & $\begin{array}{c}0.043 * * * \\
(0.00)\end{array}$ & $\begin{array}{c}-0.173^{* * *} \\
(0.03)\end{array}$ & $\begin{array}{c}-0.193^{* * *} \\
(0.01)\end{array}$ \\
\hline Hispanic & $\begin{array}{c}-0.085^{* * * *} \\
(0.00)\end{array}$ & $\begin{array}{c}0.015^{* * * *} \\
(0.00)\end{array}$ & $\begin{array}{c}0.023 * * * \\
(0.00)\end{array}$ & $\begin{array}{c}-0.202^{* * * *} \\
(0.01)\end{array}$ & $\begin{array}{c}-0.192^{* * * *} \\
(0.01)\end{array}$ \\
\hline Asian & $\begin{array}{c}-0.058^{* * *} \\
(0.02)\end{array}$ & $\begin{array}{c}0.019 * * * \\
(0.01)\end{array}$ & $\begin{array}{c}0.020^{* *} \\
(0.01)\end{array}$ & $\begin{array}{l}0.022 \\
(0.05)\end{array}$ & $\begin{array}{c}-0.108^{* * *} \\
(0.01)\end{array}$ \\
\hline Other Race & $\begin{array}{c}-0.019 * * * \\
0.00\end{array}$ & $\begin{array}{c}0.010 * * * \\
(0.00)\end{array}$ & $\begin{array}{c}-0.009 * * * \\
0.00\end{array}$ & $\begin{array}{c}-0.234^{* * *} \\
(0.00)\end{array}$ & $\begin{array}{c}-0.133^{* * *} \\
(0.00)\end{array}$ \\
\hline Constant & $\begin{array}{c}0.534^{* * *} \\
\quad(0.09)\end{array}$ & $\begin{array}{l}0.033 \\
(0.03)\end{array}$ & $\begin{array}{c}0.093^{* * *} \\
(0.03)\end{array}$ & $\begin{array}{c}0.352^{* * *} \\
(0.08)\end{array}$ & $\begin{array}{c}0.549 * * * \\
(0.07)\end{array}$ \\
\hline Observations & 147942 & 147942 & 147942 & 147942 & 147942 \\
\hline R-squared & 0.106 & 0.003 & 0.011 & 0.035 & 0.034 \\
\hline
\end{tabular}

Notes: Robust standard errors in parentheses, clustered at the state of birth level. ${ }^{* * *} p<0.01,{ }^{* *} p<0.05,{ }^{*} p<0.1$. POB: Place

(state) of birth. Occupational education is the average educational level of individuals in the chosen occupation (within sample). 
Table 3

Effects of 1919 Birth Year on Later Mortality

\begin{tabular}{|c|c|c|c|c|c|c|c|c|c|c|}
\hline $\begin{array}{l}\text { Outcome } \\
\text { Sample } \\
\text { Fixed Efffects }\end{array}$ & $\begin{array}{l}\text { Mortality } \\
\text { Full } \\
\text { Survey, } \\
\text { POB } \\
\end{array}$ & $\begin{array}{l}\text { Mortality } \\
\text { Full } \\
\text { Survey, } \\
\text { POB } \\
\end{array}$ & $\begin{array}{l}\text { Mortality } \\
\text { Male } \\
\text { Survey, } \\
\text { POB } \\
\end{array}$ & $\begin{array}{l}\text { Mortality } \\
\text { Male } \\
\text { Survey, } \\
\text { POB } \\
\end{array}$ & $\begin{array}{c}\text { Mortality } \\
\text { Female } \\
\text { Survey, } \\
\text { POB }\end{array}$ & $\begin{array}{l}\text { Mortality } \\
\text { Female } \\
\text { Survey, } \\
\text { POB }\end{array}$ & $\begin{array}{l}\text { Mortality } \\
\text { Black } \\
\text { Survey, } \\
\text { POB }\end{array}$ & $\begin{array}{c}\text { Mortality } \\
\text { Black } \\
\text { Survey, } \\
\text { POB }\end{array}$ & $\begin{array}{l}\text { Mortality } \\
\text { White } \\
\text { Survey, } \\
\text { POB } \\
\end{array}$ & $\begin{array}{l}\text { Mortality } \\
\text { White } \\
\text { Survey, } \\
\text { POB }\end{array}$ \\
\hline Year of Birth = 1919 & $\begin{array}{c}0.004 \\
(0.006)\end{array}$ & $\begin{array}{c}0.003 \\
(0.006)\end{array}$ & $\begin{array}{c}0.001 \\
(0.011)\end{array}$ & $\begin{array}{c}0.001 \\
(0.010)\end{array}$ & $\begin{array}{c}0.006 \\
(0.004)\end{array}$ & $\begin{array}{c}0.005 \\
(0.004)\end{array}$ & $\begin{array}{l}-0.006 \\
(0.013)\end{array}$ & $\begin{array}{l}-0.007 \\
(0.013)\end{array}$ & $\begin{array}{c}0.004 \\
(0.006)\end{array}$ & $\begin{array}{c}0.003 \\
(0.006)\end{array}$ \\
\hline Year of Birth & $\begin{array}{c}-0.062 * * * \\
(0.01)\end{array}$ & $\begin{array}{c}-0.059 * * * \\
(0.01)\end{array}$ & $\begin{array}{c}-0.066^{* * *} \\
(0.02)\end{array}$ & $\begin{array}{c}-0.062 * * * \\
(0.02)\end{array}$ & $\begin{array}{c}-0.061^{* * *} \\
(0.01)\end{array}$ & $\begin{array}{c}-0.058^{* * *} \\
(0.01)\end{array}$ & $\begin{array}{l}-0.003 \\
(0.04)\end{array}$ & $\begin{array}{l}0.001 \\
(0.04)\end{array}$ & $\begin{array}{c}-0.067 * * * \\
(0.01)\end{array}$ & $\begin{array}{c}-0.064^{* * *} \\
(0.01)\end{array}$ \\
\hline Year of Birth - Sq & $\begin{array}{c}0.001^{* * *} \\
0.000\end{array}$ & $\begin{array}{c}0.001^{* * *} \\
0.000\end{array}$ & $\begin{array}{c}0.001^{* *} \\
0.000\end{array}$ & $\begin{array}{c}0.001^{* *} \\
0.000\end{array}$ & $\begin{array}{c}0.001^{* * *} \\
0.000\end{array}$ & $\begin{array}{c}0.001^{* * *} \\
0.000\end{array}$ & $\begin{array}{c}0 \\
(0.001)\end{array}$ & $\begin{array}{c}0 \\
(0.001)\end{array}$ & $\begin{array}{c}0.001^{* * *} \\
0.000\end{array}$ & $\begin{array}{c}0.001^{* * *} \\
0.000\end{array}$ \\
\hline Female & $\begin{array}{c}-0.151^{* * *} \\
(0.00)\end{array}$ & $\begin{array}{c}-0.153^{* * *} \\
(0.00)\end{array}$ & & & & & $\begin{array}{c}-0.168 * * * \\
(0.01)\end{array}$ & $\begin{array}{c}-0.163^{* * *} \\
(0.01)\end{array}$ & $\begin{array}{c}-0.152^{* * *} \\
(0.00)\end{array}$ & $\begin{array}{c}-0.154^{* * * *} \\
(0.00)\end{array}$ \\
\hline Black & $\begin{array}{c}0.080^{* * *} \\
(0.01)\end{array}$ & $\begin{array}{c}0.050^{* * *} \\
(0.01)\end{array}$ & $\begin{array}{c}0.086^{* * *} \\
(0.01)\end{array}$ & $\begin{array}{c}0.045^{* * *} \\
(0.01)\end{array}$ & $\begin{array}{c}0.076^{* * *} \\
(0.01)\end{array}$ & $\begin{array}{c}0.054^{* * *} \\
(0.01)\end{array}$ & & & & \\
\hline Hispanic & $\begin{array}{c}-0.054^{* * *} \\
(0.01)\end{array}$ & $\begin{array}{c}-0.102^{* * *} \\
(0.01)\end{array}$ & $\begin{array}{c}-0.066^{* * *} \\
(0.02)\end{array}$ & $\begin{array}{c}-0.119 * * * \\
(0.02)\end{array}$ & $\begin{array}{c}-0.044 * * * \\
(0.01)\end{array}$ & $\begin{array}{c}-0.086^{* * *} \\
(0.01)\end{array}$ & & & & \\
\hline Asian & $\begin{array}{l}-0.009 \\
(0.02)\end{array}$ & $\begin{array}{l}-0.034 \\
(0.02)\end{array}$ & $\begin{array}{l}-0.024 \\
(0.02)\end{array}$ & $\begin{array}{c}-0.049 * * * \\
(0.02)\end{array}$ & $\begin{array}{l}0.006 \\
(0.03)\end{array}$ & $\begin{array}{l}-0.016 \\
(0.03)\end{array}$ & & & & \\
\hline Other Race & $\begin{array}{c}-0.205^{* * *} \\
(0.00)\end{array}$ & $\begin{array}{c}-0.222 * * * \\
(0.00)\end{array}$ & $\begin{array}{c}-0.264^{* * *} \\
(0.00)\end{array}$ & $\begin{array}{c}-0.270^{* * *} \\
(0.00)\end{array}$ & $\begin{array}{c}-0.162^{* * *} \\
(0.00)\end{array}$ & $\begin{array}{c}-0.184^{* * *} \\
(0.00)\end{array}$ & & & & \\
\hline Education & & $\begin{array}{c}-0.013^{* * *} \\
(0.00)\end{array}$ & & $\begin{array}{c}-0.015^{* * *} \\
(0.00)\end{array}$ & & $\begin{array}{c}-0.011 * * * \\
(0.00)\end{array}$ & & $\begin{array}{c}-0.007 * * * \\
(0.00)\end{array}$ & & $\begin{array}{c}-0.015 * * * \\
(0.00)\end{array}$ \\
\hline Constant & $\begin{array}{c}1.258 * * * \\
(0.097)\end{array}$ & $\begin{array}{c}1.370 * * * \\
(0.094)\end{array}$ & $\begin{array}{c}1.331^{* * *} \\
(0.168)\end{array}$ & $\begin{array}{c}1.448 * * * \\
(0.157)\end{array}$ & $\begin{array}{c}1.058 * * * \\
(0.085)\end{array}$ & $\begin{array}{c}1.156^{* * *} \\
(0.084)\end{array}$ & $\begin{array}{c}0.722 * * \\
(0.335)\end{array}$ & $\begin{array}{c}0.727^{* *} \\
(0.341)\end{array}$ & $\begin{array}{c}1.317^{* * *} \\
(0.114)\end{array}$ & $\begin{array}{c}1.450 * * * \\
(0.114)\end{array}$ \\
\hline Observations & 147942 & 147942 & 67737 & 67737 & 80205 & 80205 & 11637 & 11637 & 128695 & 128695 \\
\hline R-squared & 0.054 & 0.062 & 0.036 & 0.046 & 0.027 & 0.033 & 0.054 & 0.056 & 0.052 & 0.061 \\
\hline
\end{tabular}

Notes: Robust standard errors in parentheses, clustered at the state of birth level. ${ }^{* * *} p<0.01,{ }^{* *} p<0.05,{ }^{*} p<0.1$. POB: Place (state) of birth. 
Table 4

Effects of a 1919 Birth Year on Later Mortality by Cause of Death

\begin{tabular}{|c|c|c|c|c|c|c|c|c|c|c|c|}
\hline Cause of Death & Infectious & Neoplasm & Endocrine & Blood & Mental & Nervous & Circulatory & Respiratory & Digestive & Congenital & Injury \\
\hline \multirow[t]{2}{*}{ Year of Birth = 1919} & 0.001 & 0.005 & -0.001 & 0 & $-0.001^{* * *}$ & 0 & -0.001 & 0 & 0.001 & 0 & 0.001 \\
\hline & 0.000 & $(0.005)$ & $(0.002)$ & 0.000 & 0.000 & $(0.001)$ & 0.000 & $(0.002)$ & $(0.001)$ & 0.00 & 0.00 \\
\hline \multirow[t]{2}{*}{ Year of Birth } & $-0.004^{* * *}$ & $-0.012^{* * *}$ & -0.002 & 0.001 & 0 & 0.001 & $-0.018 * * *$ & -0.005 & $-0.003^{* *}$ & 0 & $-0.005^{* *}$ \\
\hline & $(0.001)$ & $(0.005)$ & $(0.001)$ & 0.000 & $(0.001)$ & $(0.001)$ & $(0.006)$ & $(0.003)$ & $(0.001)$ & 0.00 & 0.00 \\
\hline \multirow[t]{2}{*}{ Year of Birth - Squared } & $0.000^{* * *}$ & 0 & 0 & $-0.000 *$ & 0 & $-0.000 *$ & 0 & 0 & 0 & 0 & $0.000 * *$ \\
\hline & 0.000 & 0.000 & 0.000 & 0.000 & 0.000 & 0.000 & 0.000 & 0.000 & 0.000 & 0.00 & 0.00 \\
\hline \multirow[t]{2}{*}{ Female } & $-0.001^{* * *}$ & $-0.043^{* * *}$ & $-0.001 *$ & $-0.000 *$ & $-0.001^{* * *}$ & $-0.002 * * *$ & $-0.077 * * *$ & $-0.016^{* * *}$ & $-0.003 * * *$ & 0 & $-0.008 * * *$ \\
\hline & 0.000 & $(0.002)$ & $(0.001)$ & 0.000 & 0.000 & 0.000 & $(0.003)$ & $(0.001)$ & 0.000 & 0.00 & 0.00 \\
\hline \multirow[t]{2}{*}{ Black } & $0.005^{* * *}$ & $0.029 * * *$ & $0.007 * * *$ & 0 & $-0.001 * *$ & $-0.002 * * *$ & $0.041 * * *$ & -0.003 & $0.003^{* * *}$ & 0 & $0.002 *$ \\
\hline & $(0.001)$ & $(0.004)$ & $(0.001)$ & 0.000 & 0.000 & $(0.001)$ & $(0.006)$ & $(0.003)$ & $(0.001)$ & 0.00 & 0.00 \\
\hline \multirow[t]{2}{*}{ Hispanic } & 0 & $-0.035 * * *$ & $0.014^{* * *}$ & $-0.001 * * *$ & $-0.001^{* * *}$ & 0 & $-0.035^{* * *}$ & $-0.010^{* * *}$ & 0.002 & 0 & $-0.002 * *$ \\
\hline & 0.000 & $(0.006)$ & $(0.002)$ & 0.000 & 0.000 & $(0.001)$ & $(0.005)$ & $(0.002)$ & $(0.002)$ & 0.00 & 0.00 \\
\hline \multirow[t]{2}{*}{ Asian } & $0.003^{* * *}$ & $-0.018^{* * *}$ & $0.009 * * *$ & 0 & $0.004^{* *}$ & $-0.004 * * *$ & -0.007 & -0.005 & 0.002 & $-0.000 * * *$ & 0.002 \\
\hline & $(0.001)$ & $(0.006)$ & $(0.003)$ & 0.000 & $(0.002)$ & (0.001) & $(0.013)$ & $(0.004)$ & $(0.004)$ & 0.00 & 0.00 \\
\hline \multirow[t]{2}{*}{ Other Race } & $0.003^{* * *}$ & $-0.082 * * *$ & $-0.008 * * *$ & $0.000 * *$ & 0 & $-0.003 * * *$ & $-0.106^{* * *}$ & $-0.026^{* * *}$ & $-0.010 * * *$ & $-0.000 * * *$ & 0 \\
\hline & 0.000 & $(0.006)$ & $(0.001)$ & 0.000 & 0.000 & 0.000 & $(0.008)$ & $(0.001)$ & $(0.001)$ & 0.00 & 0.00 \\
\hline Observations & 147942 & 147942 & 147942 & 147942 & 147942 & 147942 & 147942 & 147942 & 147942 & 147942 & 147942 \\
\hline
\end{tabular}

Notes: Robust standard errors in parentheses, clustered at the state of birth level, MFX shown. ${ }^{* * *} p<0.01,{ }^{* *} p<0.05,{ }^{*} p<0.1$.

POB: Place (state) of birth. Causes not shown: "Ill defined", Skin, Musculoskeletal, and Genitourinar 
Figures

Figure 1

Mortality Rate by Birth Cohort from 1915-1923

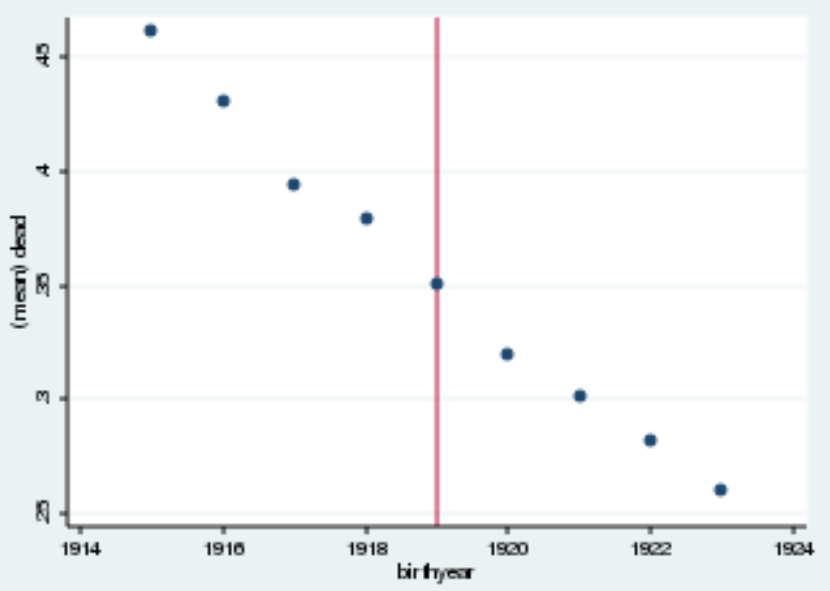

